\title{
Teaching Materials Based Problem-Solving: an Important Role in Enhancing Undergraduate Students Thinking Skills
}

\author{
Utiya Azizah* \\ Chemistry Department \\ Universitas Negeri Surabaya \\ Surabaya, Indonesia \\ utiyaazizah@unesa.ac.id
}

\author{
Harun Nasrudin \\ Chemistry Department \\ Universitas Negeri Surabaya \\ Surabaya, Indonesia.
}

\author{
Rusmini \\ Chemistry Department \\ Universitas Negeri Surabaya \\ Surabaya, Indonesia.
}

\begin{abstract}
Problem-solving is an individual's cognitive process to achieve the goals and solutions to the problem at hand. Problem-solving is a serious concern of the government of the Republic of Indonesia to prepare graduates who have high competitiveness. This study aims to describe undergraduate students' thinking skills in the material of solubility and titration results through the implementation of learning materials based problem-solving. The research design used is One Group Pretest-Posttest Design. This research was conducted in the chemistry department Universitas Negeri Surabaya with the subjects of 31 undergraduate students. This study obtained the following results: (1) Each indicator of thinking skills of the trained undergraduate students got percentage, namely identifying known knowledge $66.67 \%$, setting learning objectives $\mathbf{8 1 . 7 2 \%}$, compiling problem solving strategies $84.95 \%$, implementing problem solving strategies $82.80 \%$, making conclusions $86.02 \%$, and checking answers $64.52 \%$; and (2) N-gain scores for each indicator of thinking skills obtained have medium and high criteria. Based on the results of the study, learning materials based problem-solving have a role in improving undergraduate students' thinking skills.
\end{abstract} skills

Keywords - teaching materials, problem-solving, thinking

\section{INTRODUCTION}

The $21^{\text {st }}$ Century demands quality human resources so that they can compete in global competition. Quality human resources come from quality education processes as well, the education process undergraduate students are equipped with skills to solve problems, find alternative solutions to problem-solving, and think reflective and evaluative. These skills are thinking skills. Thinking skills are one of the life skills that need to be developed through the education process. Thinking skills are very important to equip college students to compete in a global world.

To learn chemical knowledge related to objects and natural phenomena can not be separated from thinking skills. This is because studying the objects and natural phenomena can be understood through the process of thinking in problem-solving. Undergraduate students who have good thinking skills in solving problems will easily apply their chemical knowledge in any situation and point of view [1].

Problem Solving is a directed thought to find a solution to a specific problem [2]. The learning process through Problem Solving can familiarize undergraduate students in dealing with problems in life and solve these problems skillfully to give meaning to their lives [3]. The paradigm shift in the learning process that was teacher-centered to learner-centered learning is expected to encourage undergraduate students to be actively involved in building knowledge, attitudes, and behavior. In the student-centered learning process, the ability to reason and Problem Solving is the cognitive ability of undergraduate students to build a deep understanding, which in turn can improve the quality of undergraduate student learning outcomes for the better.

Becker \& Shimada asserted that "the problem should be non-routine, in that the undergraduate student perceives the problem as challenging and unfamiliar, yet not insurmountable" [4]. Something is said to be a problem if it is stated in a problem that is not routine/ordinary where undergraduate students will consider the problem as a challenge and an unusual thing, but can still be resolved/overcome. One of the lessons that can encourage undergraduate students' thinking skills by presenting problems is learning problem-solving. Problem Solving stimulates the development of undergraduate students' thinking skills creatively and comprehensively because in their learning many undergraduate students involve mental thinking processes by highlighting problem processes from various aspects in order to find solutions [3]. In line with the statement above, that the application of Problem Solving is an effective strategy in developing undergraduate students to think scientifically and develop their reasoning ability in dealing with various life problems [5].

Undergraduate students always have high curiosity, explore, discover, learn something new, and be creative. To encourage undergraduate students' curiosity, it is necessary to 
explore what is learned, so that these exploration questions can be answered through experiments or thinking skills to find new concepts. The learning experience gained by undergraduate students from the problem-solving process will be very large. Undergraduate students will be taught and trained to have patience, perseverance, dare to take risks, and the ability to work with others. Thus, a positive learning environment will be created in the classroom so that eventually this ability will be able to be applied in solving problems in real life. This is consistent with the statement of an expert that "problem-solving requires patience, persistence, risk-taking, and cooperation, therefore a positive classroom climate is provided" [6]. Furthermore, other experts believe that "Applied problem-solving skills are critical to solving real-life problems" [7]. Thus, problemsolving based learning can help to improve undergraduate students' thinking skills.

Problem-solving models can develop a plan that implements problem-solving strategies and solutions in problem-solving so that undergraduate students are more active and solutive in creating solutions to a given problem by expressing and developing new ideas [8]. The problemsolving learning model cannot be separated from the main character, George Polya in his book entitled How to solve it, in finding problem solutions there are four steps that must be done, namely: step 1 Understood The Problem, step 2 Device a Plan, step 3 Carry Out The Plan, and step 4 Look Back [9]. The four stages of Polya's problem-solving learning model are steps to practice thinking skills.

The problem-solving competence is the accumulation of mastery of high-level thinking which includes analyzing, evaluating and creating [10]. Important elements or domains for problem-solving competencies also include exploring and understanding, representing and formulating, planning and executing and evaluating processes and reflecting (monitoring and reflecting) [11]. These thinking skills are prerequisites for solving problems.

Acquisition of concepts and thinking skills for problemsolving into one thing that is interconnected. Thinking skills for problem-solving are always practiced and acquired through specific material contexts and are very dependent on the specific domain of knowledge and its implementation strategy [12]. The results of other studies state that thinking skills for problem-solving can be obtained and mastered when presented in terms of material content [13].

Thinking skills for problem-solving that are trained in each lecture topic will enrich the undergraduate student experience because it links each material content with the application of concepts in the problem-solving process. The management of lectures is relevant to the cognitive-social theory which emphasizes that learning is a process of interaction and observing the environment through direct involvement. Learning is the process of modeling, strengthening the models and cognitive processing of the modeling. During the learning process, activities occur identifying modeling, determining the importance of the modeling process, and cognitive processing that occurs internally. Internal processing includes memory, retention, information processing, regulation of received stimulus and adjusting the cognitive structure that has been formed in a person's mind [14].

The lecture process used in this study is packaged through thinking skills to solve problems, understanding meaningful concepts, and understanding the steps of managing learning problem-solving. The lecture activities are repeated in each different topic, namely solubility and titration, thus providing sufficient experience. Repeated experiences provide opportunities for undergraduate students to gain retention of knowledge and experience, so they will be easily implemented [15]. To support the smoothness in the learning process, problem-solving based teaching materials that researchers have developed previously and are already feasible based on the validator's assessment are implemented in this study.

\section{METHODS}

This type of research is a pre-experimental research design with the design of "One Group Pretest-Posttest Design". The design of this study was carried out in one group without a comparison group. The targets of this study were 31 undergraduate students of the University of Surabaya's chemical education study program, Indonesia. The research instrument used an essay-based thinking skills test based on problem-solving that has been valid in content and construct by expert.

Measurement of undergraduate students 'thinking skills is done by giving a score on the undergraduate students' pretest and post-test answers, then the total score is converted to the total value and the percentage of achievement of each indicator is calculated. In this study, the rubric used is a rubric of thinking skills integrated with written essay tests on pre-test and post-test.

The results of this study were analyzed by descriptive quantitative. Undergraduate students are said to be successful in each of the indicators of thinking skills if they have a minimum percentage of achievement of 70. Improvements in thinking skills test results are calculated using gain scores. Descriptive analysis of $\mathrm{N}$-gain using the N-Gain criteria, namely: 1) "N-gain-high", if $<\mathrm{g}>0.7 ; 2$ ) "N-gain-medium", if $0.3<<$ g $>\leqslant 0.7$; and 3) "N-gain-low", if $<$ g $>\leqslant 0.3$. [16].

\section{RESULTS AND DISCUSSIONS}

Thinking skills are undergraduate students' skills in using concepts, principles, and theories into concrete situations in problem-solving shown by scores obtained by undergraduate students in thinking skills tests (pretest and post-test) for solubility and titration material. The questions used in measuring thinking skills are questions that require undergraduate students to carry out the process of thinking based on indicators of thinking skills namely identifying known knowledge, setting learning objectives, compiling problem-solving strategies, implementing problem-solving strategies, making conclusions, and checking answers.

After the pretest, the lecturer implements problemsolving based teaching material in the lecture process 
systematically starting from identifying known knowledge through the phenomena presented by the lecturer. Furthermore, setting learning objectives, compiling problemsolving strategies, implementing problem-solving strategies through the exploration of concepts and facts as a basis for formulating problems, formulating hypotheses, carrying out experimental procedures, making observations, taking pictures, analyzing data, formulating conclusions and ending with a checking answer.

Through the implementation of problem-solving based learning materials, obtained data undergraduate students' thinking skills in the material of solubility and titration results presented in Fig. 1.

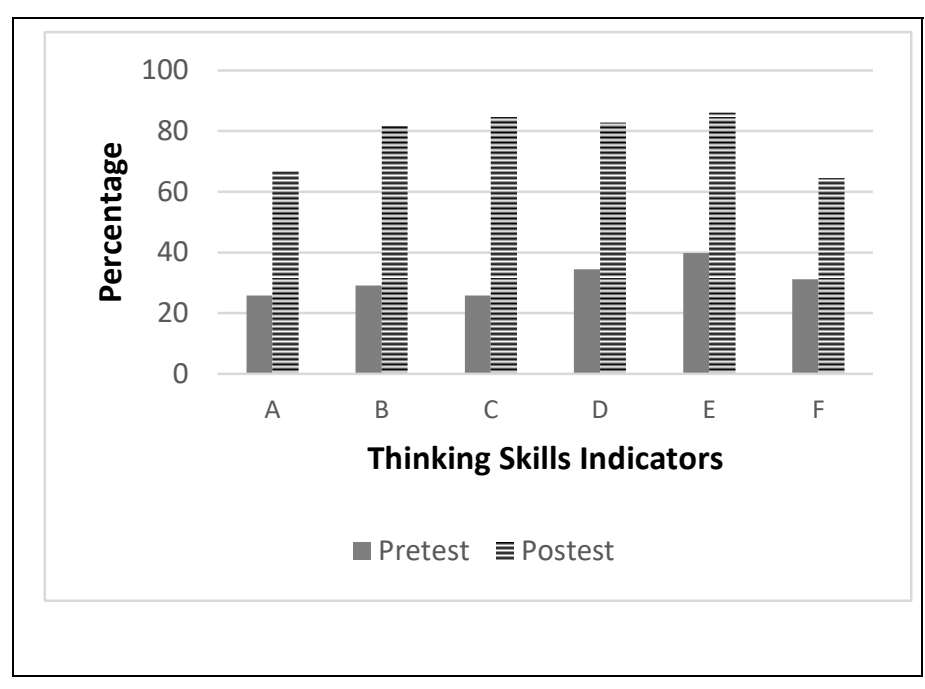

Fig. 1. Achievement of Thinking Skills Indicators

Fig. 1 shows that there are many undergraduate students who do not have thinking skills before the implementation of problem-solving based teaching materials, as indicated by the small percentage of the number of college students in thinking skills indicators namely identifying known knowledge (A), setting learning objectives (B), compiling problem solving strategies (C), implementing problem solving strategies (D), making conclusions (E), and checking answers $(F)$. The low thinking skills of undergraduate students in pretests are caused by thinking skills that have not been trained in a structured and intensive manner in lectures. After the implementation of problem-solving based teaching materials, the percentage of the number of undergraduate students increased which indicated effective problem solving based teaching materials to train college students' thinking skills. The highest percentage of thinking skills indicators are making conclusions (E). While the lowest is the checking answers (F). This fact is consistent with the results of research that states that the teachers had scientific thinking difficulties, ranging from observing to identify problems/questions, formulating hypotheses, thinking deductively, and inductive thinking, distinguishing data characteristics and processing, and drawing conclusions [17].

Based on the cognitive-social theory, that learning is modeling, reinforcement of models and cognitive processing of modeling [14], then the provision of repetitive training on the topic of solubility and titration can be seen as a modeling in studying chemical phenomena. It is possible for undergraduate students to evaluate and appreciate the steps of problem-solving to be able to plan how to study plant anatomy phenomena through problem-solving through the context of the material. which is relevant. Modeling allows the emergence of ideas and the development of concepts learned. This better result shows that problem-solving based teaching materials can improve thinking skills better, undergraduate students become more critical, both in identifying problems, issuing opinions, asking questions, and planning to solve existing problems [18].

To find out the improvement of students' thinking skills is reviewed based on the normalized gain value ( $\mathrm{N}-\mathrm{Gain})$.

TABLE I. THE RESULT OF ANALISIS N-GAIN

\begin{tabular}{|l|c|c|c|}
\hline \multicolumn{1}{|c|}{ Indicators } & $\begin{array}{c}\text { \% Pretest } \\
\text { Achievement }\end{array}$ & $\begin{array}{c}\text { \% Postest } \\
\text { Achievement }\end{array}$ & $\begin{array}{c}\text { N-Gain } \\
\text { (Criteria) }\end{array}$ \\
\hline $\begin{array}{l}\text { Identifying known } \\
\text { knowledge }\end{array}$ & 25.81 & 66.67 & $\begin{array}{c}0.55 \\
\text { (Medium) }\end{array}$ \\
\hline $\begin{array}{l}\text { Setting learning } \\
\text { objectives }\end{array}$ & 29.03 & 81.72 & 0.74 (High) \\
\hline $\begin{array}{l}\text { Compiling problem } \\
\text { solving strategies }\end{array}$ & 25.81 & 84.95 & 0.80 (High) \\
\hline $\begin{array}{l}\text { Implementing problem } \\
\text { solving strategies }\end{array}$ & 34.41 & 82.80 & 0.74 (High) \\
\hline Making conclusions & 39.78 & 86.02 & 0.77 (High) \\
\hline checking answers & 31.18 & 64.52 & $\begin{array}{c}0.48 \\
\text { (Medium) }\end{array}$ \\
\hline
\end{tabular}

Table I reveals that the increase (n-gain) of undergraduate students' thinking skills is included in the medium and high criteria, and all indicators of thinking skills have increased. Undergraduate students are said to succeed in each of the indicators of thinking skills if they have a minimum percentage of achievement of 70 . Based on Table 1, students still have not succeeded in completing two indicators namely identifying known knowledge and checking answers, even though at each meeting were trained skills of thinking used complex problem-solving. Thinking skills are trained and acquired in the context of specific material through certain strategies [19]. Implementation of problem-solving-based teaching materials allows repetition to practice thinking skills while reviewing concepts. This can improve memory through the activity of studying knowledge to obtain knowledge retention [15].

The results of thinking skills between pre-test and posttest differed significantly, the number of completed indicators reached $77.78 \%$, with the average $\mathrm{N}$-gain occupying the high category. The same N-gain category is also found in other research results [20]. Other research studies show that problem-solving based learning successfully fosters undergraduate students' problem-solving thinking skills in various academic fields [21].

To train thinking skills in solving problems is closely related to the content of the material. Instead, the material content will be well mastered if the process of acquisition through scientific thinking in solving problems. The learning 
process that occurs in each problem-solving cycle always begins by presenting material problems in the context of undergraduate students. The problem presentation can activate initial knowledge that enables undergraduate students to connect new information with existing knowledge [22]. Activities plan problem-solving, allowing students to gain experience in inquiry on complex tasks related to the material phenomenon [5].

In problem-solving, lecturers do not provide knowledge as an outcome, but undergraduate students must search and find through the activity of searching or acting as a problem solver [23]. Exploration of concepts and facts in lectures is a learning process that occurs directly and is referred to as enactive learning [14]. When undergraduate students experience learning through problem-solving, they have more potential in finding various alternative solutions to problems, developing new understanding, and increasing their ability to comprehend problems in depth [8]. Based on the description above, the implementation of problemsolving based teaching materials can improve undergraduate students' thinking skills.

\section{CONCLUSION}

Based on the results of the study, the conclusions are: 1) Each indicator of thinking skills of the trained undergraduate students got percentage, namely identifying known knowledge $66.67 \%$, setting learning objectives $81.72 \%$, compiling problem solving strategies $84.95 \%$, implementing problem solving strategies $82.80 \%$, making conclusions $86.02 \%$, and checking answers $64.52 \%$; and (2) N-gain scores for each indicator of thinking skills obtained have medium and high criteria. Based on the results of the study, problem-solving based learning materials have a role in improving undergraduate students' thinking skills.

\section{ACKNOWLEDGMENT}

The author thanks first-year undergraduate students of the Chemistry Education program as users who are directly involved in implementing to problem-solving based learning materials.

\section{REFERENCES}

[1] C. Y. Chang, 2010. "Does Problem Solving = Prior Knowledge + Reasoning Skills in Earth Science? An Exploratory Study", Res. Sci. Educ, 2010, vol 40, pp 103-116.

[2] R. L. Solso, O. H. Maclin, and M. K. Maclin, Cognitive Psychology. Eight Edition. Boston: Pearson Education, Inc., 2008.

[3] S. Djamarah, Strategi Belajar Mengajar. Jakarta : Rineka Cipta, 2011.

[4] R. McIntosh, and D. Jarret, Teaching Mathematical Problem Solving: Implementing the Vision. New York: NWREL, Mathematics and Science Education Center, 2005.

[5] M. Dogru, 2008. "The Application of Problem Solving Method on Science Teacher Trainees". Journal of Environmental \& Science Education, 2008, Vol. 3, No.1, pp. $9-18$.
[6] Demirel, Dermana, and Karagedika, A study on the relationship between reflective thinking skills towards problem solving and attitudes towards mathematics. Procedia-Social and Behavioral Sciences, 2015, Vol. 197, pp. 2086 - 2096

[7] P. H. Paul and Y. W Wang. "Problem-solving appraisal and psychological adjustment." In Oxford Handbook of Positive Psychology, 2nd ed. Edited by Charles R. Snyder and Shane J. Lopez. New York: Oxford University Press, 2009, pp. 127-38.

[8] C. M. Brenda, and N. Tyrie, Problem solving by design: Using the engineering design process to build problem solving skills for fifth graders and methods students. Science and Children, 2009, Vol. 47, No. 2, pp. 25-33.

[9] G. Polya, How to Solve It. Princeton,New Jersey: Princeton University Press, 1973.

[10] L. W. Anderson, and D. R. Krathwohl, (eds), A taxonomy for learning teaching and aAssessing. A Revision of Bloom's Taxonomy of education Objectives. New York: Addisin Wesley, 2001.

[11] OECD, PISA 2012 Assessment and Analytical Framework Mathematics, Reading, Science, Problem Solving and Financial Literacy. OECD Publishing, 2013.

[12] J. Funke, and P. A. Frensch, Complex Problem solving: The European Perspective-10 Years After, in D,H, Jonassen (ed), learning to solve complex scientific problem, New York: Lawrence Arlbarum, 2007.

[13] L. Green, and D. Ruggiero, Problem Solving through Digital Game Design: A Quantitative Content Analysis. Computers in Human Behavior, 2007, Volume 73, no. 1, pp. 28-37.

[14] R. Moreno, Educational Psychology. New York: John Wiley \& Sons, Inc, 2010.

[15] L. Destalia, Suratno, and S. Apriliya, Peningkatan Keterampilan Pemecahan Masalah Dan Hasil Belajar Melalui Penerapan Pembelajaran Berbasis Masalah (PBM) Dengan Metode Eksperimen Pada Materi Pencemaran Lingkungan. Jurnal Pancaran, 2014, Vol. 3, No. 4, pp. 213-224.

[16] R. Hake, Relationship of individual student normalized learning gains in mechanics with gender, high school physics, and pretest scores on mathematics and spatial visualization. Available: http://www.physics.indiana.edu/, 2002.

[17] Erman, Wasis, E. Susantini, U. Azizah. Scientific Thinking Skills: Why Junior High School Science teachers Cannot Use Discovery and Inquiry Models In Classroom. Atlantis Highlights in Enginering. 2018.

[18] Darmawan. "Penggunaan Pembelajaran Berbasis Masalah dalam Meningkatkan Kemampuan Berpikir Kritis Siswa pada Pembelajaran IPS di MI Darrusaadah Pandeglang”. Jurnal Penelitian Pendidikan, 2010, Vol. 11 No. 2, pp 108-115.

[19] A. M. Hoskinson, M.D. Cabalerro, and J.K. Knight, How Can We Improve Problem Solving in Undergraduate Biology? Applying Lesson From 30 Years of Physics Education Research. CBE Life Science Education. 2013. Vol. 12, No. 2, pp. 153-161.

[20] S. Wahyuni, S. Indrawati, and W. Suana, Developing Science Process Skills and Problem-Solving Abilities Based on Outdoor Learning in Junior High School, Jurnal Pendidikan IPA Indonesia, 2017, Vol. 6, No. 1, pp. 165-169.

[21] J. Hambach, C. Diezemann, and M. Tisch, Assessment of Students' Learn Competencies with the Help of Behavior Video Analysis-Are with the Help of Behavior Video Analysis-Are Good Students Better Problem Solver?.Procedia CIRP, 2016, Vol. 55, pp. 230 - 235.

[22] H.G. Schmidt, J.I. Rotgans, H.J. Elaine, and E.H. Yew, (2011). The Process of Problem-Based Learning: What Works And Why. Medical Education, 2011, Vol. 45, No. 8, pp. 792-806.

[23] H. Syofyan, and A. Halim, Penerapan Metode Problem Solving Pada Pembelajaran IPA Untuk Peningkatan Kemampuan Berpikir Kritis Siswa. In Prosiding Seminar Nasional Multi Disiplin Ilmu \& Call For Papers UNISBANK (SENDI_U) KE-2. 2016. 